\title{
Prospects and challenges of gender neutralization in Russian
}

\author{
Yana Kirey-Sitnikova' ${ }^{1}$
}

Accepted: 1 April 2021 / Published online: 21 May 2021

(c) The Author(s) 2021

\begin{abstract}
Feminist linguistic activism has gained prominence among Western feminists as a way to eliminate sexism in language and everyday life. In Russian, gender specification (known as feminitivy) represents the mainstream approach practiced by grassroots feminist reformers. However, alternative approaches aimed at gender neutralization proliferate. The paper examines the prospects and challenges of gender neutralization both in writing and oral speech. Results of a survey documenting attitudes of Russian-speaking feminist and LGBTQI communities to language reform attempts are presented, with a special focus on comparison between gender specification and gender neutralization.
\end{abstract}

\section{Introduction: Feminist linguistic activism}

Feminist linguistic activism is a practice that aims to expose and eliminate linguistic sexism across languages. By "linguistic sexism" most authors generally mean "asymmetrical treatment [in language] of women and men, of male/masculine and female/feminine concepts and principles" (Pauwels, 2003, p. 553), with male/masculine constructed as the norm ("maleas-norm" ideology) and female/feminine as deviation from that norm (Spender, 1980). Linguistic sexism is commonly illustrated by the high prevalence of "generic masculines" in languages with grammatical gender and "male generics" elsewhere (Hellinger \& Bußmann, 2015 , p. 9), with grammatically or semantically masculine forms (including pronouns) used to refer to all human beings by default regardless of their actual sex, gender or gender identity, while grammatically feminine forms are regarded female-specific. In many cases, feminine forms are derived from masculine forms morphologically by suffices and other means. Moreover, linguistic sexism occurs in other areas, including forms of address, idiomatic expressions, proverbs (e.g. Holmes, 2000; Pershai, 2014), and a plethora of other linguistic imbalances between the speech of women and men (Lakoff, 2004).

Not satisfied with merely exposing linguistic sexism, some feminists seek to establish a "gender-fair" alternative through comprehensive language reforms. The theoretical framework most often cited by early feminist reformers is the controversial Sapir-Whorf hypothesis of linguistic relativity (Schneider \& Foss, 1977). This theory argues that, at least to some degree, the language we speak influences our basic categories of thought (Lucy, 2001). If

Y. Kirey-Sitnikova

yanasitnikova@protonmail.ch

1 Sahlgrenska Academy, University of Gothenburg, Gothenburg, Sweden 
this hypothesis is true then the use of English words like "he", "chairman" or "fireman" creates the perception that all such individuals are men. It follows that replacing these words with their "female" equivalents might eliminate this "male-as-norm" ideology. However, Australian feminist Dale Spender, who was among the pioneers to call for language reforms, advocates for a more holistic approach. Spender believes that this process must be a dialectical rather than a unidirectional one. She argues:

As more meanings are changed so will society change and the sexist semantic rule be weakened; as society and the semantic rule changes so will more meanings changeeven without deliberate intervention. To concentrate on either word meanings or social organizations - to the exclusion of the other - is to invite failure (Spender, 1980, p. 31).

Contemporary scholars and activists arguing for gender-fair language seem to prefer to cite empirical evidence rather than the Sapir-Whorf hypothesis. For example, societies where gendered, natural gender and genderless languages are spoken have been shown to differ in gender equality in a statistically significant way (Prewitt-Freilino et al., 2012). However, on the whole, development of gender-fair language remains largely the domain of activists and amateur linguists, with theoretical foundations playing a secondary role.

Conceived in the wake of second-wave feminism in the United States (US), feminist linguistic activism is currently evolving in two dimensions. First, mainstream feminist reformatory approaches are being challenged to be more inclusive of trans and gender nonbinary individuals by, among other factors, a trans and queer critique of second-wave feminism's binary and essentialist notions of sex and gender (e.g. that the categories of men and woman are immutable and polarized). Second, feminist linguistic activism is spreading, mainly within the Western world, to languages other than English. This pilot study aims to capture both of these dimensions by documenting emerging linguistic practices and attitudes among Russian-speaking feminist and LGBTQI communities, with a particular focus on gender neutralization and trans communities.

The next section of this paper (Section 2) outlines and provides insight into the gender specification vs. gender neutralization debate that informs this study. Section 3 documents non-standard language use in written Russian. Section 4 presents the results and documents oral speech strategies. Section 5 explores the attitudes of Russian-speaking feminist and LGBTQI individuals towards various types of non-standard language use. Finally, Sect. 6 talks about this study's limitations and avenues for further research in this area.

\section{Gender-neutralization or gender-specification: between ideology and pragmatism}

Gender specification and gender neutralization are two main and largely opposite approaches to combating sexism in language (Pauwels, 2003, p. 556). By introducing feminine forms, proponents of gender specification (or feminization) explicitly state that, because men are not the default example of what is human, masculine generics should not be applied to all human beings by default. Gender-neutralization, on the other hand, seeks to eradicate all references to gender in language.

Although both approaches were developed to counter the "male-as-norm" ideology, their end-goals differ and, since they cannot be implemented simultaneously, compete. Pauwels (2003, p. 556) classifies arguments used by proponents of the two approaches into social and 
linguistic categories. While social arguments mainly focus on the social effectiveness of reform and ideological issues, linguistic arguments emphasize linguistic viability and language typology. This paper contributes to this debate by introducing the standpoint of transgender individuals and demonstrates why, in languages not well suited for gender neutralization (including Russian), this approach is still on the table.

\subsection{Social arguments for trans/non-binary inclusion and gender-neutral language}

The basic lines of argumentation between proponents of either feminization or neutralization were drawn in the 1970 to 1980 s, which is also when these debates were ignited, largely by cisgender feminists. At that time, social arguments were synonymous with social effectiveness of language reforms; for instance, whether a proposed reform has a chance to gain prominence within the society (e.g. Henley, 1987).

Since the 1980's, new stakeholders, like transgender, gender non-binary and nonconforming people, have appeared. These groups provide an impetus to rethink social arguments in a broader sense. Trans (including non-binary) activists contribute to this by raising awareness that not all individuals feel comfortable describing themselves or being labeled with traditional "female" and "male" designations. A growing number of individuals choose to identify as "genderqueer", "agender", "neutrois", "genderfluid”, "third gender", or another identity entirely. These communities are, subsequently, increasingly expressing dissatisfaction with traditional notions, and therefore linguistic conventions and restrictions, regarding feminine and masculine forms (Hord, 2016). Many such individuals, in striving for new linguistic solutions, argue that their identities are not currently represented. It is, however, not viable to accommodate all the multitude of non-binary identities via separate grammatical genders for each. On the other hand, creating a "homogenized" category for all trans people would lead to othering (i.e. assigning certain individuals to an out-group, essentially different from one's own) without addressing the core oppression (Pershai, 2006). A more straightforward and radical path is to do away with, or make optional, grammatical gender altogether.

Another argument raised in favor of gender-neutral language is the ability to avoid the potential to misgender an individual whose gender identity is unknown. That is physical appearance is not always a good predictor of one's gender identity or the way they wish to be addressed. Research shows that perpetual misgendering (i.e. being addressed in a gender other than one prefers), whether intentionally or not, is often perceived as a microaggression (Freeman \& Stewart, 2018, see also Nordmarken, 2014) and leads to psychological distress in trans individuals (McLemore, 2018). Communicative problems in pre-transition trans individuals can also be caused by the need to use specific gendered forms of speech in order to hide or obscure one's gender identity, especially in societies that are particularly transphobic (Zborovskaya, 2012).

For a theoretical linguist, insistence on such a rigid correlation between one's gender identity and referential gender might come as a surprise or be evidence of ignorance, since it is not necessarily always the case. In some Polish dialects, for example, unmarried women are addressed in neuter or masculine forms (Corbett, 1991, p. 100). This is, nevertheless, not evidence of their identification as male or non-binary. Gender shifts are used in many languages to express a range of emotions, from affection to disdain (Aikhenvald, 2019). Many studies in LGBT linguistics demonstrate the cultural phenomenon whereby cisgender male homosexuals use feminine pronouns to refer to themselves and each other and cisgender lesbians similarly use masculine forms of address (Livia \& Hall, 1997). From the standpoint of post-structuralist linguistics, the whole concept of stable referential gender is questionable, 
since it "impl[ies] an essentialist existence independent of discursive formation" (Motschenbacher, 2010, p. 82).

This critique, while theoretically and empirically well-founded, comes from cisgender linguists who might face epistemological barriers to understanding specific experiences of trans individuals. This is subsequently reflected in their use of language and priorities in language planning efforts. An influx of trans people in academia has provided new insights and led to the emergence of trans linguistics as a new and distinct field (Zimman, 2020). Scholars working within this field consider the experience of trans people with language, including referential self-determination and constraints posed at self-expression by cisgenderist society, as central to understanding both social and grammatical gender (Ibid.; Zimman, 2019). An explicit focus on the trans perspective is productive in redefining and broadening the concept of linguistic sexism to include misgendering which is currently overlooked in mainstream feminist language planning in favor of male generics (Ansara \& Hegarty, 2013). Following this logic, one might wonder whether a "gender-fair" label can be applied to gender specification - an approach that excludes those outside the female/male dichotomy?

\subsection{Pragmatic linguistic arguments against neutralization and the ways to overcome}

Even when eagerly desired, not every language easily succumbs to gender neutralization. Generally, one can differentiate between three types of languages according to how gender is coded: genderless languages, natural gender languages and grammatical gender (or gendered) languages (Stahlberg et al., 2007). Genderless languages are already gender-neutral by default, thus, they will not be given further consideration. Natural gender languages, like English or Swedish, reflect gender in personal pronouns and can be made gender-neutral by incorporating gender-neutral pronouns - singular they and hen being the oft-cited examples. Consider, however, that some less common gender-neutral pronouns (e.g. ze) might be considered trans-specific by the general public and may lead to outing of users as trans individuals (Hord, 2016).

Grammatical gender languages, such as Russian, present the most serious challenge to gender neutralization. In these languages not only personal pronouns but most other parts of speech have at least two forms - feminine and masculine. While neuter is present in Russian, it it is not of much practical use here, since it is reserved for inanimate objects and used for humans only in derogatory speech and a few terms referring to small children (ditja, čado). Given these circumstances, gender-specification is the choice by default, while gender-neutralization is rarely considered by feminist language reformers - see Plemenitaš (2014) for a discussion on Slovenian, and Kiełkiewicz-Janowiak (2019) for Polish.

The social arguments in favor of gender neutralization raised above, however, still apply in societies where languages are not particularly fit for such a reform. In these cases activists seeking to move their languages in this direction are obliged to invent completely new forms, such as through the use of special symbols. A few examples can help understand the difficulties involved. In French, gender neutral variants of the word "students" incorporate a period (étudiant.e.s), a middle point (étudiant·es) or hyphen (étudiant-e-s) (Shroy, n.d). In Spanish, the use of an at-sign (tod@s), asteriks $\left(\operatorname{tod}^{*} s\right)$, the letter $x(\operatorname{tod} x s)$ and an underscore (tod_s) have all been proposed in place of the "a" and "o" used to delineate feminine or masculine forms respectively (Melamud, 2017, p. 19). In German, methods include an asterisk (Studier*, Student*in), $x$-form (Studierx), internal capital I (StudentIn), and an underscore (Student_in, Stu_dentin) (Hermann, 2003; AG Feministisch Sprachhandeln, 2014). The underscore method, known as "gender gapping", was introduced in 2003 to represent a visual 
"gap" between a masculine form and a feminine suffix (Hermann, 2003). Gender-gapped words are intended to include everyone in-between female and male gender identities. The relative usability of this method in German is explained by -In being the most productive suffix for derivation of feminine forms.

In summation, language typology puts great constraints on the choice of the optimal strategy for eliminating language sexism. Natural gender languages are better suited for neutralization, while gendered languages better succumb to feminization. Nevertheless, social arguments may have an outsized impact, leading to the creation of peculiar forms. To use a catchphrase, "where there's a will there's a way".

\section{Non-standard language use in Russian-speaking feminist and LGBTQI communities: evidence from written sources}

Androcentrism of the Russian language is well documented (Doleschal \& Schmid, 2001). Language reforms have been attempted since the beginning of Soviet rule. Feminine forms, known as feminitivy (or feminativy), were purposefully promoted by the Soviet government with an aim to engage more women in public life and eliminate gender inequality (Pershai, 2015). Deliberate linguistic reforms are, therefore, not a new phenomenon in the Russian sphere and feminitivy are currently discussed in both popular and academic literature (e.g. Fufaeva, 2020). On the other hand, gender neutralization is a new phenomenon rarely discussed by Russian linguists and known to small but growing communities of LGBTQI people (Andreevskikh et al., 2017; Ovčinnikova, 2017; Klestova, 2020; Zborovskaya, 2014 being a few exceptions).

This section will provide an overview of the main types of non-standard language use among Russian-speaking feminist and LGBTQI communities. The discussion is based on both primary and, where available, secondary data.

\subsection{Gender specification (feminization)}

Feminization is not the main topic of this paper, and interested readers are referred to Mozdzierz (1999) and Doleschal and Schmid (2001) for an overview of formation of feminine forms in Russian, Berkutova (2018) on historical trends, Badanina (2017), Vorob'eva (2020) and similar works on present-day debates.

\subsection{Paired forms}

Paired masculine and feminine noun forms can be used side by side to refer to a mixed-gender group (1):

(1) Zamykala demonstraciju 'Radužnaja kolonna', v kotoroj prinjali ucastie okolo 600 celovek — predstavitel'nicy i predstaviteli LGBT-soobščestv, LGBT-aktivistki i aktivisty, sojuznicy i sojuzniki LGBT.

'Bringing up rear was the 'Rainbow column', in which participated around 600 individuals - representatives (f.) and representatives (m.) of LGBT-communities, LGBT-activists (f.) and activists (m.), allies (f.) and allies (m.) of LGBT.'

(Coming Out, 2015)

The obvious drawback is unwieldiness resulting from repeated use of each word. As a result, in official settings, an abbreviated form using two gendered suffices (separated with a slash) 
is mainly used: e.g. sotrudniki/cy ('employees'). The later suffix may also appear in brackets: e.g. sotrudniki(-cy).

This method will not lead to true neutralization, since the result is little more than a combination of masculine and feminine forms and excludes everything outside the femininemasculine binary. To include non-binary options, "others" can be added, e.g.: podrugi, druz'ja i drugie suščnosti ('friends (f.), friends (m.) and other beings') (Kiberfeminizm, 2020).

\subsection{Neuter gender}

Some non-binary individuals address their linguistic exclusion by adopting and reappropriating neuter gender forms (2):

(2) - Rasskaži podrobno o momente, kogda ty osoznalo sebja agendernym čelovekom. / - Po golove udarilo - i osoznalo. Na samom dele kak uznalo o kategorii gendera, tak i osoznalo.

- - Tell in detail about the moment, when you realized (n.) you are an agender person. / - It hit me on the head - and realized (n.). In fact when [I] learned (n.) about the category of gender, so [I] realized (n.).'

(Agadžikova, 2018)

The stigma surrounding the use of neuter towards humans precludes this approach from gaining popularity. Moreover, neuter shares endings with masculine in several declensions and is, therefore, not always perceived as truly gender neutral.

\subsection{Singular they}

One approach to gender neutralization is inspired by the use of singular they in English. For a comprehensive discussion of this method see (Ovčinnikova, 2017). We will restrict ourselves here to considering just one example (3) from that study for illustration (Frisk and Chara are characters in a video game Undertale):

$$
\begin{aligned}
& \text {... ne sčitaja Frisk, kotorye okazyvaetsja Čaroj ... } \\
& \text {... not to mention Frisk, who (pl.) turn out (sing.) to be Chara ...' }
\end{aligned}
$$

The relative pronoun kotorye is used in plural to refer to a single non-binary person. In this example, it is followed by the singular verb okazyvaetsja. The name Frisk is not declined, while Chara is declined as feminine, though both character are non-binary. As noted in the original study, the usage of number and declension does not follow a strict pattern and depends on the author and context (Ibid.).

\subsection{Gender-gapping}

An alternative approach to gender neutralization was inspired by German-speaking queer feminists' use of gender-gapping to represent "everything in-between" masculine and feminine (Aloevrukava-blog, 2014). Let us consider two examples ((4), (5)) to illustrate the use and formation of these forms:

(4) Na volne populjarnosti gendernyx issledovanij mnogie lingvist_ki načali pisat' o jazyke ‘čerez prizmu gendera', xotja togda, kak i sejčas, malo kto ob”jasnjal_a, čto imenno ispol'zovanie ètogo podxoda predpolagaet.

'In the wake of popularity of gender studies many *linguists started to write about 
language 'through gender prism', although then, as now, few people *explained, what exactly the use of this approach implies.'

(Pershai, 2017, p. 64)

Xotja Pidžin (kotor_aja predpočitaet mestomenie 'on_a') otmečaet, čto podderžal_a by...

'Although Pidgeon (*who prefers the pronoun 'they') notes, that [they] would support...'

(Davis, 2018, p. 98)

The first example comes from an article on gender linguistics and employs gender-gapped nouns and verbs in the place of generic masculine forms (lingvisty, ob"jasnjal) to refer to a group of "linguists" that includes women, men and (probably) individuals of other gender identities. The second example comes from a translation of an English academic book and demonstrates the use of gender-gapped personal and relative pronouns and a verb to express non-binary identity of a third person (in the original, singular they is used).

In formation of Russian gender-gapped words two deviations from the respective approach in German are observed. First, gender-gapping is applied not only to nouns but to others parts of speech, including pronouns and verbs: for example, masculine form $o b$ "jasnjal is supplemented with a feminine ending - $a$, separated by a gender gap (underscore). Secondly, Russian morphology is much richer, so, in the case of lingvist_ki, the plural ending $-y$ is removed before gender-gapping is applied: lingvisty $\rightarrow$ lingvist $\rightarrow$ lingvist_ki. Matters become even more complicated when a feminine form is not derived from a masculine one, but derivation of masculine and feminine employs pairs of parallel suffices. In such cases, activists recommend using the longest common substring, followed by an underscore and a feminine ending: e.g. perevodčiki (m. 'translators') / perevodčicy (f. 'translators') $\rightarrow$ perevodči $\rightarrow$ perevodči_cy. (Aloevrukava-blog, 2014). Therefore, the gender gap loses its original meaning as a "space between" masculine and feminine and becomes a space between a senseless fragment of a word and its feminine ending. A few words completely defy gender neutralization in this way due to rather different masculine and feminine forms: e.g. drug / podruga (m./f. 'friend'). Conversely, some feminine forms derived from masculine counterparts may have completely different meanings: e.g. mašinist ('train driver') and mašinistka (f. 'typist'), making gender-gapping senseless in such cases.

Acknowledging deficiencies and contradictions of the method, its creators nevertheless "choose not to pay attention, because the idea is more or less easy to grasp and because I think that cis-men for once need to use fantasy, just like everyone else has been doing it for decades" (Aloevrukava-blog, 2014).

\section{Non-standard language use in Russian-speaking feminist and LGBTQI communities: oral speech}

Written strategies of creating a gender-fair language exemplified in the previous section can be transferred to oral speech with varying success. Oral articulation of feminitivy via paired forms and words in neuter is straightforward but less obvious in the case of approaches borrowed from English and German. Moreover, oral speech may provide speakers with opportunities that are not easily expressed in writing. An online survey was conducted to shed light on this topic.

\subsection{Method}

Written questionnaires are a relatively underused approach in sociolinguistic research. They are praised for large sample sizes produced, low cost and time invested, and easiness of 
analysis (Boberg, 2013). The method is also preferred for low-frequency variables (Bailey et al., 1997). On the other hand, asking direct questions about language use may lead to an "observer's paradox" and answers provided may better capture respondents' attitudes to language use than the way they actually speak (Boberg, 2013). Nevertheless, in some circumstances written surveys can produce valid data comparable in accuracy to fieldwork methods (Dollinger, 2012).

Given the exploratory nature of this study, a written survey was chosen as the easiest possible way to draw a broad picture of oral language use in an extremely understudied population of Russian-speaking LGBTQI individuals and feminists. Its use is further justified by the author's intention to study both language use and attitudes to such innovations, which would otherwise require separate studies.

An online survey was created using Google Forms and advertised to the social networks of groups devoted to feminist, LGBT, queer and intersex issues. The form provided a brief explanation of key terms, followed by 14 questions (Appendix 1). The participants were self-selected and the first three questions were used to establish eligibility (membership in LGBTQI and/or feminist communities). The scope of the initial survey was broader than that of the present article. In reporting the results, answers to questions will be reordered to give a more logical presentation. Thus, in this section, results on oral language use with a focus on gender neutralization will be reported, while Sect. 5 is devoted to attitudes to non-standard language use.

\subsection{Results}

The questionnaire form was open for answers from 28 July 2016 to 18 October 2016 when the number of participants reached 1400 and initial overview of the results showed saturation. Based on the answers to the first three questions (gender identity, identification with feminism and LGBTQI communities), the number of eligible responses was reduced to 1205.

\subsubsection{Gender neutralization strategies in oral speech}

Many respondents revealed that in oral speech they rely on the same ways of gender neutralization that they use in writing. Notably, gender gaps did not defy oral articulation to the extent that might be imagined. One respondent used "a pause in place of a gender gap between a neutral stem and a feminine suffix" (Resp. 125, genderfluid, demigirl). Other respondents resorted to gesticulation to "draw the gap in the air with a finger" (Resp. 418, genderqueer) or "spell out endings as if reading a word with a gender gap (literatorki-y or literatory-ki)" (Resp. 1128, woman).

The results show that oral speech gives more flexibility to express gender neutrality than writing. One popular method includes using impersonal or indefinite personal structures: tak slučilos', čto mne predložili novuju rabotu ('It so happened that I was offered a job') (Resp. 650, agender), or mne slučilos' pojti... ('It so happened to me to go'), mne prišlos' pozvonit'... ('It was necessary for me to call'), kak mne kazalos'... ('As it seemed to me') (usually it introduces a factor of "fate" in the narrative, as if nothing depends on me) (Resp. 305).

Shifting focus from one's own actions to another person or an object is a variation of this strategy: ja uvlekalsja risovaniem ('I enjoyed drawing') $\rightarrow$ u menja bylo uvlečenierisovanie ('There was my hobby — drawing'), ja rabotal ('I worked') $\rightarrow$ u menja byla rabota ('There was my job') (Resp. 49, genderqueer), or včera xodila v teatr ('Yesterday I went to a theater') $\rightarrow$ včera byl otličnyj večer v teatre ('Yesterday was a great evening in the theater') (Resp. 57, woman). 
A similar approach is substituting description of past actions with their result in the present: ja prigotovil_a užin ('I cooked dinner') $\rightarrow$ užin gotov ('The dinner is ready') (Resp. 784, genderqueer). Using present and future in situations where past would normally be used: $i$ vot ja prixožu tuda, a tam mne govorjat ('And so I come there, and I am told') (Resp. 20, woman, genderqueer), or ja pošla $v$ magazin ('I'm going to a shop') $\rightarrow$ ja sejčas pojdu $v$ magazin ('I will now go to a shop') (Resp. 181, nonbinary).

Other methods mentioned include swallowing the endings, using "we" instead of "I", using infinitive instead of the correct past form of the verb, rhetorical questions, etc. When addressing third persons, additional approaches $((6),(7),(8))$ are:

(6) I use neutral constructions, address others with vy ('you') or talk about things and actions [not individuals] (Resp. 49, genderqueer).

(7) Phrases with the world ljudi ('people'): trans-ljudi ('trans people'), ljudi, zanimajuščiesja aktivizmom ('people doing activism') (Resp. 55).

(8) When possible, I try to use neutral words: ljudi, narod ('people'), kto-to ('someone') + present tense, plural (Resp. 961, genderqueer).

One respondent said that she is "trying to articulate endings in an unclear and silent way, so that the gendered ending could not be heard" (Resp. 751, woman). A couple of respondents have invented completely new gender neutral words or endings: "Eёgo, ejmu... )) I think it's better to invent words of neuter gender" (Resp. 208), or "Sometimes I invent forms of words (not lingvisty and lingvistki, but lingvist ̇̇)" (Resp. 1269, woman). Finally, some respondents inserted foreign words in their speech.

\subsubsection{Contextual use of gender in self-reference}

Some participants noted that they used different genders to refer to themselves. Several trans people noted that they prefer to misgender themselves in public places to avoid transphobia, while reserving their preferred gender for use among friends. This is more a necessity than preference:

It's not always easy to talk neutrally, thus sometimes I'm obliged to talk about oneself on masculine or feminine. I use the gender corresponding to sex assigned at birth in situations where it is known (documents, work, official business, with relatives and colleagues who are unaware). In other cases, it depends on how people perceive me and whichever is safer. For example, if I look masculine today, then I feel it's safer to use masculine gender in speech, and vice versa (Resp. 961, genderqueer).

Some respondents switch gender in emotionally charged situations, depending on the mood and topic: "Depends mostly on emotional condition and theme. For example, I more often use feminine when talking about childhood" (Resp. 661, genderqueer), or "Masculine, when I want to focus on the action itself and its external consequences, and feminine, when I want to focus on my own impression/perception of the situation" (Resp. 60).

Finally, some (presumably cis) women use masculine forms on the internet to avoid misogyny or because they are shorter. 


\section{Attitudes of Russian-speaking LGBTQI and feminist individuals to feminist linguistic reforms: results of a survey}

Whichever advantages and disadvantages of the aforementioned methods exist from the perspective of a linguist, their viability depends on those who use them in real life. Thus, attitudes to language use are of particular import. This pilot study reports attitudes among two partly overlapping communities (feminist and LGBTQI) among which non-standard language is particularly widespread.

\subsection{Method}

Direct measurement is taken from among the three popular approaches to studying attitude to language (Garrett, 2010). For this study, the same survey of feminist and LGBTQI identifying individuals was used, as described above. The questions related to language attitudes are Q4-Q6 and Q8.

\subsection{Results}

Answers revealed mixed attitudes towards language reforms. The common themes raised in arguments supporting these reforms include: (a) silencing of women in language should come to an end; (b) human language is a dynamic construct, therefore the advent of new forms is natural; (c) new forms look strange at first sight but one gets easily accustomed to them. The arguments against language reforms include that: (a) new forms look/sound bad; (b) such reforms distract feminists from more serious concerns; (c) "coercive" reforming by a small minority will never be accepted by society at large; (d) reforms should be guided by professional linguists, not amateurs. These arguments are similar to those used by critics of the reforms in other languages, and partly correspond to classical arguments recorded by Maija Blaubergs back in 1980.

Most of the survey respondents answers to this question implicitly or explicitly related to feminitivy, but not gender neutralization. This is because feminitivy remain most clearly associated with feminist language reforms. Nevertheless, some mentioned neutralization as well. A portion of respondents expressed no strong preference for either feminization or neutralization, considering them to be complementary, not competing approaches: "feminitivy are a major step in combating gender discrimination. This is the basis for future development of a neutral language for all genders" (Resp. 833, woman).

Other comments explicitly compare and contrast the two approaches. Among the proponents of gender neutralization who are critical of feminitivy, the main argument was reluctance to emphasize sex and/or gender of the person concerned:

Feminitivy make visible the women whose achievements are often being silenced. On the other [hand], [I] would like to use gender neutral words for everyone. [I] don't like emphasizing sex and gender of a person (Resp. 195, trans man).

I don't approve any types of ghettoization of women, as well as rigid juxtaposition of men and women, emphasizing differences between them. I believe feminitivy place emphasis on differences. I prefer neutrality in the issues of gender (Resp. 1004, woman).

Some transgender and gender non-binary respondents claim that enforced gender binarism in language, promoted by feminitivy, could negatively impact their ability to express (or conceal, when necessary) their gender identity: 
Compulsory use of feminitivy such as "authoress" and so on will significantly aggravate the lives of gender non-binary and transgender people, since [it] will make them publicly "define themselves" in relation to sex, thus, if previously a person in a hostile environment could talk about oneself as "I am an author", without specifying "I am a man" or "I am a woman", now he will either refer to himself according to the biological gender or forcefully make an involuntary coming-out. I wouldn't even mention the people who do not feel either M or F, for whom there's no place in this scheme, as if they do not exist (Resp. 253, agender).

On the other hand, a number of proponents of feminitivy expressed strong reservations about gender neutralization. Their opposition was mostly related to unreadability of words with gender gaps:

[I] support feminitivy, [I am] strongly against gender gaps, they confuse and impede one from reading a written text by slowing down comprehension: in a phrase there should be one word, but not an invitation for the reader's brain to select each time which [form] is more convenient (Resp. 583, woman).

Even those who support gender neutralization for ideological reasons (inclusion), complain about inconvenience of gender gaps:

Underscores make the text feel cumbersome $<\ldots>$ But it is [this method] that I find the most "correct" (Resp. 290, non-binary genderfluid).

Gendergap is disastrously inconvenient, but necessary to include gender nonconforming people (Resp. 595, woman).

Though still other respondents praised gender gaps for brevity:

[gender gap] require the least number of characters, in modern world brevity is important (Resp. 42, genderqueer).

The language always goes in the direction of short forms, for this reason I support the form aktivistki_ty. That is, try to designate but in a brief way (Resp. 89, identity unknown).

At least one respondent claimed that the cumbersome nature of such methods is also an advantage: "Brackets and dashes visually overload the text, but I like it: "stumbling" over them while reading makes people think about gendered endings and those to whom they refer to" (Resp. 961, genderqueer).

Only one participant explicitly rejected gender neutralization as a strategy on the grounds that it leads to the silencing of women: "[I am] strongly against gender neutralization. Silencing leads to worsening of the situation of women" (Resp. 563, woman).

\section{Limitations and further directions}

This article is the first of its kind to attempt to give a broad picture of feminist language reforms and non-standard language use in Russian-speaking feminist and LGBTQI communities. Its broadness has two obvious downsides: the data comes from different sources obtained with different methods and many topics are mentioned in only a perfunctory way. More in-depth research into these topics is clearly warranted. The proposed directions include: 
1. Concentrate on specific groups such as trans people, cisgender individuals, lesbian women, etc.;

2. Collect data on oral language use with in-person interviews and observational studies, paying special attention to phonology in the case of trans people;

3. Analyze written language use in a systematic way using methods of corpus linguistics;

4. Study attitudes towards trans/feminist language reforms and non-standard language use among the general population.

\section{Conclusion}

Gender neutralization and feminization are two alternative approaches to feminist language reforms aimed at overcoming masculine-centrism in many languages. The choice between these approaches is based not only on linguistic typology, but also on socio-cultural reasoning and political commitment. In Russian, feminization in the form of feminitivy is the predominant approach, but there is a strong demand for a gender-neutral alternative on behalf of transgender and especially gender non-binary individuals. As the survey shows, there is a strong demand for this among Russian-speaking LGBTQI and feminist communities. Three methods to approach gender-neutrality are used in writing: neuter gender, singular they and gender-gapping. All of them have significant drawbacks limiting their spread in the communities that employ them. Gender neutralization strategies in oral speech include using impersonal or indefinite personal structures, plural instead of singular, infinitive instead of the correct past form of the verb, and rhetorical questions.

Feminist and LGBTQI participants in this study expressed mixed attitudes towards feminist linguistic reforms. There is a discord between those who perceive language as a static rule-based system and those who are more open to linguistic innovation and creativity. Further divides result from differing priorities set by proponents of particular approaches: while some participants emphasize practical concerns such as simplicity, readability and pronounceability, others focus on inclusion of the whole spectrum of gender identities. Although the survey was not intended to capture awareness on specific approaches to linguistic reforms, the results hint that feminization (feminitivy) may be the best available approach, while gender-gapping remains the best known of gender neutralization methods.

The current study has a number of limitations and invites further research into nonstandard language use among Russian-speaking feminist and LGBTQI communities.

\section{Appendix 1: Questionnaire}

\section{Отношение к феминитивам и гендерной нейтрализации в русском языке}

Опрос призван собрать данные об отношении к феминистским лингвистическим реформам в русском языке, а именно к феминитивам и гендерной нейтрализации. Феминитивы-это слова женского рода, альтернативные словам, традиционно употребляемым в мужском роде, напр.: “активистка”, “авторка”, “директорка”... Гендерная нейтрализация-это попытка говорить и писать, не употребляя гендерированных форм, либо с использованием комбинации двух гендерированных форм, напр.: вместо “психолог” или “психологиня” $\rightarrow$ “психолог_иня”. Опрос является анонимным.

Q1. Ваша гендерная идентичность (напр.: женщина, мужчина, транс-мужчина, гендерквир...) 
Q2. Относите ли Вы себя к каким-либо направлениям феминизма?
a) Анархо-феминизм
b) Интерсекциональный феминизм
c) Квир-феминизм
d) Лесбийский феминизм
е) Либеральный феминизм
f) Радикальный феминизм (транс* инклюзивный)
g) Радикальный феминизм (транс* эксклюзивный)
h) Сепаратистский феминизм
i) Социалистический феминизм
j) Трансфеминизм
k) Экофеминизм
1) Не считаю себя феминисткой (-ом), но положительно отношусь к феминизму
m) Отношусь негативно к феминизму / Антифеминизм
n) Other:

Q3. Относите ли Вы себя к ЛГБТКИ-людям?

- Да, отношу

- Нет, не отношу

- Other:

Q4. Как вы в целом относитесь к феминистским реформам русского языка?

- Полностью поддерживаю

- Скорее поддерживаю, чем не поддерживаю

- Безразлично

- Скорее не поддерживаю, чем поддерживаю

- Резко не поддерживаю

Q5. Считаете ли Вы, что изменение языка поможет уничтожить гендерную дискриминацию?

- Скорее поможет

- Скорее не поможет

- Не знаю

- Гендерной дискриминации не существует

- Other:

Q6. Если Вы хотите оставить подробные комментарии, то можете это сделать здесь

Q7. Какие средства феминизации и гендерной нейтрализации языка Вы используете при письме?

- Употребляю только феминитивы (напр.: “активистки”)

- Употребляю феминные и маскулинные формы через “и” (напр.: “активистки и активисты")

- Употребляю феминную форму полностью + окончание маскулинной через косую черту (напр.: “активистки/-ы”)

- Употребляю маскулинную форму полностью + окончание феминной через косую черту (напр.: “активисты/-ки”)

- Употребляю феминные окончания в скобках (напр.: “активисты (-ки)”) 
- Употребляю маскулинные окончания в скобках (напр.: “активистки (-ы)”)

- Употребляю подчёркивания (напр.: “активист_ки”)

- Не использую ничего из этого

- Other:

Q8. Какие преимущества и недостатки Вы видите у вышеприведённых языковых средств? Какие считаете наиболее перспективными?

Q9. Какие средства феминизации и гендерной нейтрализации Вы используете в устной речи?

Q10. В каком роде Вы себя чаще называете?

- Женский

- Мужской

- Средний

- Стараюсь говорить о себе гендерно-нейтральным языком

- Other:

Q11. Если Вы стараетесь говорить о себе гендерно-нейтральным языком, то какие языковые средства для этого используете? В случае затруднений с лингвистической терминологией, приведите примеры предложений

Q12. Если Вы говорите о себе в разных родах, поясните, в каких ситуациях какой род Вы используете

Q13. Считаете ли Вы, что Ваша жизнь была бы лучше, если в русском языке не было бы грамматического рода?

- Определённо да

- Скорее да, чем нет

- Скорее нет, чем да

- Определённо нет

- Не знаю

- Other:

Q14. Здесь Вы можете оставить любые дополнительные комментарии и пожелания по опросу

Acknowledgements I would like to express my gratitude to Noah Adams for proofreading and valuable comments on this paper.

Funding Note Open access funding provided by University of Gothenburg.

Open Access This article is licensed under a Creative Commons Attribution 4.0 International License, which permits use, sharing, adaptation, distribution and reproduction in any medium or format, as long as you give appropriate credit to the original author(s) and the source, provide a link to the Creative Commons licence, and indicate if changes were made. The images or other third party material in this article are included in the article's Creative Commons licence, unless indicated otherwise in a credit line to the material. If material is not included in the article's Creative Commons licence and your intended use is not permitted by statutory regulation or exceeds the permitted use, you will need to obtain permission directly from the copyright holder. To view a copy of this licence, visit http://creativecommons.org/licenses/by/4.0/. 


\section{References}

Agadžikova, A. (2018). “Ty mal'čik ili devočka?”: agendernye ljudi rassuždajut o svoej identičnosti. Afisha. Retrieved March 25, 2021, from https://aily.afisha.ru/relationship/8601-ty-malchik-ili-devochkaagendernye-lyudi-rassuzhdayut-o-svoey-identichnosti/.

AG Feministisch Sprachhandeln der Humboldt-Universität zu Berlin (2014). Was tun? Sprachhandelnaber wie? W_Ortungen statt Tatenlosigkeit! Retrieved March 25, 2021, from http://feministischsprachhandeln.org/.

Aikhenvald, A. Y. (2019). Endearment, respect, and disdain through linguistic gender. ReVEL-Revista Virtual de Estudos da Linguagem, 17(16), 1-22.

Aloevrukava-blog (2014). Jazykovoe tvorčestvo protiv diskriminacii: kak pridumyvat' novye slova i pravila. Kefir i sigarety. Retrieved March 25, 2021, from https://aloevrukava-blog.tumblr.com/post/ 82019290971/.

Andreevskikh, O., Pershai, A., \& Sitnikova, Y. (2017). Genderno-nejtral'nyj jazyk i nebinarnye identičnosti: kak reformirovat' jazyk? Makeout.by. Retrieved March 25, 2021, from https://makeout.by/2017/02/27/ genderno-neytralnyy-yazyk.html.

Ansara, Y. G., \& Hegarty, P. (2013). Misgendering in English language contexts: Applying non-cisgenderist methods to feminist research. International Journal of Multiple Research Approaches, 7(2), 160-177. https://doi.org/10.5172/mra.2013.7.2.160.

Badanina, I. V. (2017). Funkcionirovanie feminativov v jazyke interneta. In A. V. Dolžnikova \& V. V. Barabaš (Eds.), Russkij jazyk v internete: ličnost', obščestvo, kommunikacija, kul 'tura: Sbornik statej I meždunarodnoj naučno-praktičeskoj konferencii. Moscow: Peoples’ Friendship University of Russia.

Bailey, G., Wikle, T., \& Tillery, J. (1997). The effects of methods on results in dialectology. English WorldWide, 18(1), 35-63. https://doi.org/10.1075/eww.18.1.03bai.

Berkutova, V. V. (2018). Feminatives in the Russian language: historical aspect. Filologičeskij aspekt, 11(43).

Blaubergs, M. S. (1980). An analysis of classic arguments against changing sexist language. Women's studies international quarterly, 3(2-3), 135-147. https://doi.org/10.1016/S0148-0685(80)92071-0.

Boberg, C. (2013). Surveys: The use of written questionnaires in sociolinguistics. In C. Mallinson, B. Childs, \& G. Van Herk (Eds.), Data collection in sociolinguistics: Methods and applications. Abingdon, Oxfordshire, UK: Routledge.

Coming Out (2015). LGBT-aktivistki i aktivisty trebujut privleč Vitalija Milonova k otvetstvennosti za reči nenavisti. ComingOutSpb.com. Retrieved March 25, 2021, from https://comingoutspb.com/news/ milonov1may/.

Corbett, G. G. (1991). Gender. Cambridge, Cambridgeshire, UK: Cambridge University Press.

Doleschal, U., \& Schmid, S. (2001). Doing gender in Russian: structure and perspective. In M. Hellinger \& $\mathrm{H}$. Bußmann, Gender across languages: the linguistic representation of women and men, 1 . Amsterdam/Philadelphia: John Benjamins Publishing Company.

Davis, G. (2018). Spory ob interseksnosti: somnitel'nyj diagnoz (A. Berezkin, Trans.). Associacija russkojazyčnyx interseks ljudej (Original work published 2015).

Dollinger, S. (2012). The written questionnaire as a sociolinguistic data gathering tool: Testing its validity. Journal of English Linguistics, 40(1), 74-110. https://doi.org/10.1177/0075424211414808.

Garrett, P. (2010). Attitudes to language. Cambridge, Cambridgeshire, UK: Cambridge University Press.

Hellinger, M., \& Bußmann, H. (2015). Gender across languages: The linguistic representation of women and men. In M. Hellinger \& H. Bußmann (Eds.), Gender across languages, Vol. 1. Amsterdam/Philadelphia: John Benjamins Publishing Company.

Henley, N. M. (1987). This new species that seeks a new language: On sexism in language and language change. In J. Penfield (Ed.), Women and language in transition. Albany, NY: State University of New York Press.

Hermann, S. K. (2003). Performing the Gap: Queere Gestalten und geschlechtliche Aneignung. arranca! Retrieved March 25, 2021, from https://arranca.org/archive?path= $\% 2$ Fausgabe $\% 2 F 28 \% 2$ Fperformingthe-gap.

Holmes, J. (2000). Ladies and gentlemen: Corpus analysis and linguistic sexism. In C. Mair \& M. Hundt (Eds.), Corpus linguistics and linguistic theory. Amsterdam: Rodopi.

Hord, L. C. (2016). Bucking the linguistic binary: Gender neutral language in English, Swedish, French, and German. Western Papers in Linguistics/Cahiers linguistiques de Western, 3(1), 4.

Freeman, L., \& Stewart, H. (2018). Microaggressions in clinical medicine. Kennedy Institute Ethics Journal, $28(4), 411-449$.

Fufaeva, I. (2020). Kak nazyvajutsja ženščiny. Feminitivy: istorija, ustrojstvo, konkurencija. Moscow: Izdatel'stvo AST.

Kiberfeminizm (2020, September 24). Podrugi, Druz’ja i Drugie Suščnosti! Kiberfeminizm. Retrieved January 23, 2021, from https://vk.com/wall-126967570_2484.

Kiełkiewicz-Janowiak, A. (2019). Gender specification of Polish nouns naming people: language system and public debate arguments. Slovenščina 2.0, 7(2), 141-171. 
Klestova, Y. V. (2020). Sredstva gendernoj nejtralizacii v anglijskom i russkom jazykah. In N. V. Butylov (Ed.), Aktual'nye problemy obščej teorii jazyka, perevoda, mežkul 'turnoj kommunikacii i metodiki prepodavanija. Saransk: Afanas'ev V. S.

Lakoff, R. T. (2004). Language and woman's place: Text and commentaries. New York, NY: Oxford University Press.

Livia, A., \& Hall, K. (1997). Queerly phrased: Language, gender, and sexuality. New York, NY: Oxford University Press.

Lucy, J. A. (2001). Sapir-Whorf Hypothesis. In N. J. Smelser \& P. B. Baltes (Eds.), International encyclopedia of the social \& behavioral sciences, Vol. 11. Amsterdam: Elsevier.

McLemore, K. A. (2018). A minority stress perspective on transgender individuals' experiences with misgendering. Stigma and Health, 3(1), 53. https://doi.org/10.1037/sah0000070.

Melamud, A. (2017). El Masculino Genérico (Master's thesis). Argentina, Buenos Aires: Instituto Superior de Letras Eduardo Mallea.

Motschenbacher, H. (2010). Language, gender and sexual identity: Poststructuralist perspectives. Amsterdam/Philadelphia: John Benjamins Publishing Company.

Mozdzierz, B. M. (1999). The rule of femininization in Russian. In M. H. Mills (Ed.), Slavic gender linguistics. Amsterdam/Philadelphia: John Benjamins Publishing Company.

Nordmarken, S. (2014). Microaggressions. TSQ: Transgender Studies Quarterly, 1(1-2), 129-134.

Ovčinnikova, A. A. (2017). Strategija snjatija gendernoj opredelënnosti: jazykovye sredstva i diskursivnye uslovija realizacii. Tomsk State University. Retrieved January 23, 2021, from http://vital.lib.tsu.ru/vital/ access/manager/Repository/vital:5205.

Pauwels, A. (2003). Linguistic sexism and feminist linguistic activism. In M. Meyerhoff \& J. Holmes, The handbook of language and gender. Maiden, MA: Blackwell Publishing Ltd.

Pershai, A. (2006). The language puzzle: Is inclusive language a solution? In K. Scott-Dixon (Ed.), Trans/Forming Feminisms: Transfeminist Voices Speak Out. Toronto: Sumach Press.

Pershai, A. (2014). Semantika pola. Vilnius: European Humanities University.

Pershai, A. (2015). Snova o jazykovom seksizme. Journal “Ja”, 1(37).

Pershai, A. (2017). "Kolonizacija naoborot” pjatnadcat' let spustja: ob osobennostjax razvitija postsovetskoj gendernoj lingvistiki. Crossroads, $1-2$.

Plemenitaš, K. (2014). Gender ideologies in English and Slovene: a contrastive view. ELOPE: English Language Overseas Perspectives and Enquiries, 11(1), 17-29. https://doi.org/10.4312/elope.11.1.17-29.

Prewitt-Freilino, J. L., Caswell, T. A., \& Laakso, E. K. (2012). The gendering of language: A comparison of gender equality in countries with gendered, natural gender, and genderless languages. Sex roles, 66(3-4), 268-281. https://doi.org/10.1007/s11199-011-0083-5.

Schneider, M. J., \& Foss, K. A. (1977). Thought, sex, and language: The Sapir-Whorf hypothesis in the American women's movement. Women's Studies in Communication, 1(1), 1-7. https://doi.org/10.1080/ 07491409.1977.11089617.

Shroy, A. (n.d). Innovations in Gender-Neutral French: Language practices of nonbinary French speakers on Twitter (unpublished Master's thesis). Retrieved March 25, 2021, from https://www.academia.edu/ 33393890/.

Spender, D. (1980). Man made language. Abington, Oxfordshire, UK: Routledge \& Kegan Paul.

Stahlberg, D., Braun, F., Irmen, L., \& Sczesny, S. (2007). Representation of the sexes in language. In K. Fiedler (Ed.), Social communication. New York, NY: Psychology Press.

Vorob'eva, A. S. (2020). Feminitivy-neologizmy v lingvističeskom aspekte. In Gorizonty sovremennoj rusistiki: sbornik statej Meždunarodnoj naučnoj konferencii, posvjaščennoj jubileju akademika V. G. Kostomarova. Moscow: Pushkin State Russian Language Institute.

Zborovskaya, T. (2012). Verbal'noe neraskrytie osoznavaemogo pola kak faktor defektivnogo obščenija $\mathrm{V}$ processe transseksual'nogo perehoda. In Conference for Young Researchers of the Institute of Linguistics of the Russian Academy of Sciences. Retrieved March 25, 2021, from https://transgenderlinguistics. wordpress.com/2012/11/06/.

Zborovskaya, T. (2014). Govorit’ o sebe: praktiki utverždenija ili umalčivanija identičnosti govorjaščego. In Čelovek včera i segodnja: meždisčiplinarnye issledovanija, 8. Moscow: Russian Academy of Sciences, Institute of Philosophy.

Zimman, L. (2019). Trans self-identification and the language of neoliberal selfhood: Agency, power, and the limits of monologic discourse. International Journal of the Sociology of Language, 2019(256), 147-175. https://doi.org/10.1515/ijsl-2018-2016.

Zimman, L. (2020). Transgender language, transgender moment: Toward a trans linguistics. In K. Hall \& R. Barrett (Eds.). The Oxford Handbook of Language and Sexuality. Oxford Handbooks Online. https://doi. org/10.1093/oxfordhb/9780195182057.001.0001.

Publisher's Note Springer Nature remains neutral with regard to jurisdictional claims in published maps and institutional affiliations. 